\title{
Bioassay
}

\section{Establishment and control of Tribolium castaneum (Herbst, 1797) (Coleoptera: Tenebrionidae) with inert dusts in stored canola}

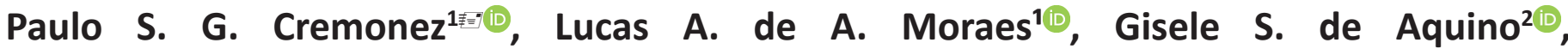 \\ Renato R. Machado', Rafael Hayashida ${ }^{2}$, Virginia Sousa ${ }^{3 \oplus}$, Pedro M. O. J. Neves \\ ${ }^{1}$ State University of Londrina - UEL, Londrina, Brazil. ${ }^{2}$ Federal University of Parana - UFPR, Curitiba, Brazil. ${ }^{3}$ Pedagogical University, \\ Niassa Delegation - UP-Niassa, Lichinga, Mozambique \\ 㭋CCorresponding author: paulogimz@gmail.com
}

\section{Edited by: Regiane O. Bueno}

Received: October 11, 2019. Accepted: January 08, 2020. Published: April 13, 2020.

\begin{abstract}
Tribolium castaneum (Herbst, 1797) is know as one of main pests of stored canola seeds worldwide, however, the cases of infestation in Brazil are still not reported. Due to its potential pest status allied to the increasing production of canola in Brazil, this work aims to evaluate the establishment of $T$. castaneum in canola stored seeds, as well as the effects of diferent inert dusts to its control. For stablishment determination, three substrates were tested: wheat bran (control); whole wheat seeds; and whole canola seeds. The insects remained in the substrates for 14 days, when mortality was counted, and then for aditional seven days before get removed, for progeny assessment at 66 days after initial exposure. For the insecticide potential of inert dusts, four treatments were tested in canola seeds as substrate: diatomaceous earth; basaltic rock powder; vegetable charcoal powder; and untreated canola seeds as control treatment. The beetles were exposed to the treated substrate and cumulated mortality was counted each two days for 15 days. Lower adult mortality and higher progeny in canola seeds indicates that these substrate is a potential host for T. castaneum. Diatomaceous earth and vegetable charcoal powder reduced the survival of adult beetles in canola in more than $60 \%$ at the end of the evaluation period. The T. castaneum adults and its offspring develops well in stored canola seeds. Additionally, the use of inert dusts, mainly diatomaceous earth and vegetable charcoal powder presents promising results of control of the beetle in stored canola seeds.
\end{abstract}

Keywords: stored products pests, inert powders, agro-energetics, pest control.

Canola (Brassica napus L. var. oleifera) has great potential for biodiesel production. Canola crops stand out for being the second most cultivated among oilseeds in the world, behind only to soybean. The 2019-20 harvest projections indicate a total production of 69 million tons, a little reduction compared to the same period of last year, especially due to general decrease in oilseeds production in this window, however a number up to $50 \%$ compared to the last decade (USDA-FAS 2019). In Brazil, is cultivated in the Central-West, Southeast and South of the country, where the cultivation had demonstrated excellent potential for future increase (Silva et al. 2017).

The use of sustainable energy as an alternative for non-renewable resources, such as diesel oil of fossiliferous source, should consider the exploitation of potential crops for biodiesel production, responsible for moving the productive chain of the increasing development sector known as agro-energetics (Kohlhepp 2010).

The red flour beetle Tribolium castaneum (Herbst, 1797) (Coleoptera: Tenebrionidae) is a polyphagous and cosmopolitan stored grain pest and presents an extreme adaptation, supported by the presence of a cryptonephridial kidney-like organ, in its body, that allows its establishment in extreme low humidity conditions (Richards et al. 2008).

In Brazil, T. castaneum is considered a secondary pest that occur in corn, wheat and rice, and its presence is usually indicative of the establishment of other pests, such as other weevils (Coleoptera: Curculionidae) (Lorini et al. 2015). However, some authors state that its importance is such or even greater than some primary pests (Trematerra et al. 2000).

Studies on T. castaneum as a pest in canola in Brazil are still nonexistent. However, it is known that it causes economic damage in stored oilseeds and is considered one of the main pests of canola stored seeds in the major producing regions of the world, viz. Canada (Yu et al. 2017), Australia (Nayak et al. 2017) and the Middle East (Khashaveh et al. 2009).

The use of inert dusts for pest control in stored grain is of long standing and represents a good alternative to synthetic pesticides, commonly used for T. castaneum control. However, several reports of pesticide resistance and detoxification mechanisms were made in the past (Champ \& Campbell-Brown 1970; Zettler \& Cuperus 1990), and in the recent years (Kalsi \& Palli 2017; Nayak et al. 2017; Malekpour et al. 2018).

The growing importance of canola cultivation in Brazil may put $T$. castaneum in a position as an important pest, as has been observed worldwide. Thus, the aims of this study were to evaluate establishment and spread potential of $T$. castaneum in canola storage seeds, as well as your control by using different inert dusts.

Adults of $T$. castaneum were obtained from established colony maintained in constant environment room at the Laboratory of Entomology/CCA of State University of Londrina, Londrina, Brazil, and multiplied in a pesticide-free wheat bran as standard food. Unsexed adults were removed and placed in plastic container $(V=500 \mathrm{~mL})$, with around 300 beetles each, covered with voile fabric fastened with a rubber band to allow gaseous exchange. The beetles were supplied with only wheat bran as food.

The colony, as well as every step in this study were kept under controlled conditions of $25 \pm 2^{\circ} \mathrm{C}, 12 \mathrm{~h}$ of photophase and $60 \pm 5 \%$ of $\mathrm{RH}$.

To evaluate the adaptability capacity of $T$. castaneum in stored canola seeds it was compared the establishment of the beetle in three different substrates (treatments): whole canola seeds (lapar PCI-0801, 
generously gifted by Dr. P. M. de Araújo); whole grain organic wheat $\left(\right.$ Ecobio $\left.^{\circledR}\right)$; and the colony standard food (pestifice-free wheat bran) as control treatment.

The experimental unit consisted in $50 \mathrm{~g}$ of each treatment inside a cylindrical glass vial $(\mathrm{V}=250 \mathrm{~mL}$ ) were 30 adult beetles randomly collected from the stock colony were placed in, then covered with voile fastened with a rubber band. The mortality analyses were recorded every two days until the 14th day after initial exposure (14 DAE), for the determination of cumulative mortality values.

To evaluate the progeny establishment, the methodology proposed by Khashaveh et al. (2009) was used. The survival insects remained for seven days after the mortality evaluation (=21 DAE) and then they were removed. The vials containing the substrate and eggs were kept untouched for another 45 days (=66 DAE) in the determined controlled conditions. After this period, the total number of larvae, pupae and adults emerged in the treatments were quantified and relatively compared (\%) with the number of insects emerged from the organic wheat bran (control).

To access the control potential of inert dusts over $T$. castaneum, seeds of canola were coated with four treatments: diatomaceous earth (Keepdry $\left.{ }^{\mathrm{TM}}\right)(\mathrm{DE})$; basaltic rock powder (ultrafine microgabbro) (RP); Eucalyptus grandis W. Hill ex Maiden commercial charcoal powder (CP); and untreated canola seeds as control treatment.

In order to evaluate and compare each one of the products over the development of the beetle in canola seeds, the dusts were not associated with each other at this study. Each treatment was used at $2 \%$ dosage mixed in a plastic bag with canola seeds ( $12 \pm 1 \%$ moisture), being vigorously agitated for about 2 min.

After the treatment $50 \mathrm{~g}$ of treated canola seeds were added in glass vial $(V=250 \mathrm{~mL})$ and unsexed adult insects $(n=30)$ placed on the same day of the treatment coating.

For the two bioassays, a completely randomized design was adopted. In the evaluation of $T$. castaneum adaptability to canola seeds five repetitions were performed, and the cumulative mortality was evaluated every two days over a period of 14 days. At the end of the mortality evaluation, the number of progeny insects emerged from each substrate were compared, in percentage, with the control treatment. The data were subjected to ANOVA and the means compared by Tukey test $(p \leq 0.05)$.

In the bioassay with inert dusts were used one single dosage for each of the four treatments, and four repetitions per treatment were carried out. The mortality data were submitted to ANOVA and means compared by Tukey test $(p \leq 0.05)$.
Mortality averages indicate that $T$. castaneum have potential to adapt to canola seeds of lapar $\mathrm{PCl}-0801$ variety. The population maintained in canola seeds remained practically unaltered from 4 to $8 \mathrm{DAE}$, a significantly similar pattern to the beetle populations at control substrate until the last observations (Tab. 1). The T. castaneum mortality on whole wheat seeds was higher than the other treatments. In another study, T. castaneum did not affected wheat grains evaluating its germination after 120 days of exposure (Dal Bello et al. 2018). This probably occur due the capacity of the beetle in colonize preferentially deteriorated seeds for its establishment.

It was observed a significant reduction in the percentage of larvae, pupae and adults in whole wheat seeds when compared to both with control treatment (wheat bran) and with canola seeds at the final period (66 DAE) (Tab. 2). A significant higher emergence of adults in Canola seeds was also observed. These data show that $T$. castaneum development is favored when it feeds on canola seeds compared to the treatment with wheat bran seeds.

The results observed in the tabs. 1, 2 also show that $T$. castaneum did not establish as well in whole grains of wheat related to those in wheat bran and canola seeds. Wheat is the most cited stored grain where the T. castaneum is a pest in Brazil (Lorini et al. 2015), and its establishment in this substrate may be even more important than other insects that are considered primary stored wheat pests (Trematerra et al. 2000)

These data point out that the behavior of $T$. castaneum as a secondary pest is by the need of an initial injury in the integument of the hard wheat grain (Rees 2008). However, the establishment of this pest in intact canola seeds, observed in this study, could be possible because of physical characteristic of the canola seed in relation to wheat, which is softer by the accentuated lipid constitution (Zaderimowski \& Sosulski 1978). Thus, this study may indicate that as well as in countries that lead the production of canola crops (Rees 2008; Khashaveh et al. 2009; Yu et al. 2017), T. castaneum has the potential to become an important stored grain pest of canola.

The application of inert dusts in seeds affected the development of adult's insects, as well as the establishment of the progeny. The main control agents observed were diatomaceous earth (DE) and charcoal powder (CP), with mortality rates that have reached 100 and $60 \%$ at the end of the evaluation period (14 DAE), respectively (Tab. 3). The rock power treatment showed a cumulative mortality of only $25 \%$.

The DE granules abrasive action can cause grooves in insect cuticle, further affecting the development of insect larvae which have thinner cuticle than adults, inducing increased loss of water (Lomakin et al.

Table 1. Mortality ( $\% \pm \mathrm{SE}$ ) of Tribolium castaneum adults established on different substrates under laboratory conditions ( $25 \pm 1$ 으; $12 \mathrm{~h}$ photofase and $65 \pm 5 \% \mathrm{RH})$. Londrina, Brazil, 2017

\begin{tabular}{llllllll}
\hline \multirow{2}{*}{ Substrate } & \multicolumn{7}{c}{ Mortality (\% \pm SE) } \\
\cline { 2 - 8 } & 2 DAE & 4 DAE & 6 DAE & 8 DAE & 10 DAE & 12 DAE & 14 DAE \\
\hline Whole wheat seeds & $6.0 \pm 0.6 \mathrm{a}$ & $14.0 \pm 0.9 \mathrm{a}$ & $24.0 \pm 1.7 \mathrm{a}$ & $28.0 \pm 1.9 \mathrm{a}$ & $33.0 \pm 1.8 \mathrm{a}$ & $36.0 \pm 1.9 \mathrm{a}$ & $38.0 \pm 1.7 \mathrm{a}$ \\
Wheat bran (control) & $5.0 \pm 0.4 \mathrm{a}$ & $7.0 \pm 0.4 \mathrm{~b}$ & $11.0 \pm 0.7 \mathrm{~b}$ & $13.0 \pm 0.7 \mathrm{~b}$ & $14.0 \pm 0.9 \mathrm{~b}$ & $14.0 \pm 0.9 \mathrm{~b}$ & $16.0 \pm 0.7 \mathrm{~b}$ \\
Canola seeds & $9.0 \pm 1.0 \mathrm{a}$ & $13.0 \pm 0.7 \mathrm{a}$ & $13.0 \pm 0.6 \mathrm{~b}$ & $13.0 \pm 0.6 \mathrm{~b}$ & $15.0 \pm 0.8 \mathrm{~b}$ & $17.0 \pm 0.9 \mathrm{~b}$ & $18.0 \pm 0.9 \mathrm{~b}$ \\
\hline
\end{tabular}

*Means followed by the same letter in a column do not differ significantly according to Tukey test ( $p \leq 0.05)$. SD: Standard error; DAE: Days after exposure. $n=750$.

Table 2. Number (\%₫SE) of the different stages of Tribolium castaneum progeny established in different substrates 66 days after initial exposure under laboratory conditions ( $25 \pm 1$ 으; $12 \mathrm{~h}$ photofase and $65 \pm 5 \% \mathrm{RH}$ ). Londrina, Brazil, 2017

\begin{tabular}{|c|c|c|c|c|c|c|}
\hline \multirow[b]{2}{*}{ Substrate } & \multicolumn{2}{|c|}{ Larvae } & \multicolumn{2}{|c|}{ Pupae } & \multicolumn{2}{|c|}{ Adults } \\
\hline & $\begin{array}{l}\text { Individuals } \\
\text { (n } \pm \text { SE) }\end{array}$ & $\begin{array}{c}\text { Relative } \\
\text { proportion to } \\
\text { control (\%) }\end{array}$ & $\begin{array}{c}\text { Individuals } \\
\text { (n } \pm \text { SE) }\end{array}$ & $\begin{array}{c}\text { Relative } \\
\text { proportion to } \\
\text { control }(\%)\end{array}$ & $\begin{array}{c}\text { Individuals } \\
\text { (n } \pm \text { SE) }\end{array}$ & $\begin{array}{c}\text { Relative } \\
\text { proportion to } \\
\text { control (\%) }\end{array}$ \\
\hline Whole wheat seeds & $1.4 \pm 0.3 a$ & -89.86 & $0.4 \pm 0.0 \mathrm{a}$ & -71.43 & $1.2 \pm 0.2 \mathrm{a}$ & -62.50 \\
\hline Wheat bran (control) & $13.8 \pm 0.9 b$ & - & $1.4 \pm 0.2 b$ & - & $3.2 \pm 0.3 b$ & - \\
\hline Canola seeds & $12.6 \pm 1.2 b$ & -9.70 & $1.8 \pm 0.3 b$ & 28.57 & $4.2 \pm 0.5 c$ & 31.25 \\
\hline
\end{tabular}

Note: means followed by the same letter in a column do not differ significantly according to Tukey test $(p \leq 0.05)$. SE: Standard error. 


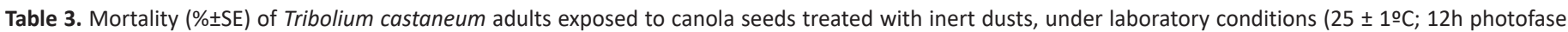
and $65 \pm 5 \%$ RH). Londrina, Brazil, 2017.

\begin{tabular}{|c|c|c|c|c|c|c|c|}
\hline \multirow{2}{*}{ Treatment } & \multicolumn{7}{|c|}{ Mortality (\%₫SE) } \\
\hline & 2 DAE & 4 DAE & 6 DAE & 8 DAE & 10 DAE & 12 DAE & 14 DAE \\
\hline Untreated canola seed (control) & $0.0 \pm 0.0 a$ & $0.0 \pm 0.0 a$ & $0.0 \pm 0.0 \mathrm{a}$ & $0.0 \pm 0.0 a$ & $0.0 \pm 0.0 a$ & $0.0 \pm 0.0 a$ & $1.7 \pm 0.2 \mathrm{a}$ \\
\hline Rock dust & $0.0 \pm 0.0 a$ & $1.7 \pm 0.2 \mathrm{a}$ & $3.3 \pm 0.2 a$ & $10.0 \pm 0.8 a$ & $18.3 \pm 0.6 a$ & $21.7 \pm 0.9 b$ & $25.0 \pm 0.4 b$ \\
\hline Charcoal powder & $1.7 \pm 0.2 b$ & $15.0 \pm 0.4 b$ & $21.7 \pm 1.7 b$ & $38.3 \pm 2.0 \mathrm{~b}$ & $46.7 \pm 2.3 b$ & $50.0 \pm 2.1 c$ & $60.0 \pm 1.1 c$ \\
\hline Diatomaceous earth & $68.3 \pm 0.5 c$ & $73.3 \pm 0.2 b$ & $73.3 \pm 0.2 b$ & $74.7 \pm 0.2 b$ & $100.0 \pm 0.0 c$ & $100.0 \pm 0.0 c$ & $100.0 \pm 0.0 c$ \\
\hline
\end{tabular}

${ }^{*}$ Means followed by the same letter in a column do not differ significantly according to Tukey test ( $\left.\mathrm{p} \leq 0.05\right)$. ${ }^{1} \mathrm{SE}$ : Standard error; ${ }^{2} \mathrm{DAE}$ : Days after exposure; ${ }^{3} \mathrm{C} . \mathrm{V}$ : Coefficient of variation. $n=360$.

2010). Additionally, these damages may increase the efficiency of associated control methods, such as foster entomopathogenic fungi infection in the cuticle, as seen in another studies with $T$. castaneum (Dal Bello et al. 2018). For this reason, DE may be the best suited method to the control of this $T$. castaneum in stored canola seeds, being an economically viable product and which may affect the establishment of the insect in the substrate, reducing the adult's viability.

Little is known about the activity of CP on of stored grain pests. In Sitophilus orizae (Linnaeus, 1793) (Coleoptera: Curculionidae) this inert powder showed no effects on mortality, but in the emergence of adults (progeny) when applied in stored maize seeds (Sitoe 2013). The CP associated with the entomopathognic fungus Metarhizium anisolpliae (Metschn, 1879) Sorokin, 1883 reduced populations of T. castaneum in infested wheat grains (Batta \& Abu Safieh 2005). Our results are promising and feature the viability of charcoal dust as a control agent for this beetle in canola.

Another possibility for control is the integration of inert powders with reduced dosages of chemical inseciticides. It is known that reduced dosages of cyromazine and pirimiphos-methyl significantly reduces T. castaneum larvae viability, compromising its adult establishment (Kamaruzzaman et al. 2006).

The development of $T$. castaneum offspring demonstrated a trend of good development in canola seeds in terms of larval and pupal development, and also demonstrate that adults are favored by the oleaginous. Additionally, the use of inert dusts, mainly diatomaceous earth and vegetable charcoal powder presents promising results of control of this stored grain pest in canola seeds.

\section{Acknowledgements}

The authors thank P. M. Araújo of Agronomic Institute of Paraná - IAPAR, for the concession of canola seeds, to the Department of Agronomy-UEL for the laboratory support, and CAPES/ Araucaria Foundation for the financial support (Process number 88882.168655/2018-01).

\section{Authors' contributions}

Conceptualization: Cremonez, P. S. G.; Moraes, L. A. A.; Aquino, G. S. Bioassays development: Cremonez, P. S. G.; Moraes, L. A. A.; Machado, R. R.; Hayashida, R.; Sousa, V. Data analysis: Cremonez, P. S. G. Writing and editing: Cremonez, P. S. G.; Moraes, L. A. A. Reference analysis: Cremonez, P. S. G.; Hayashida, R.; Neves, P. M. O. J. Final draft correction: Neves, P. M. O. J.

\section{References}

Batta, Y. A.; Abu Safieh, D. I. (2005) A study of treatment effect with Metarhizium anisopliae and four types of dusts on wheat grain infestation with Red flour beetles (Tribolium castaneum Herbst, Coleoptera: Tenebrionidae). Journal of the Islamic University of Gaza, 13(1): 11-22.

Champ, B.; Campbell-Brown, M. (1970) Insecticide resistance in Australian Tribolium castaneum (Herbst) I. A test method for detecting insecticide resistance. Journal of Stored Products
Research, 6(1): 53-70. doi: 10.1016/0022-474x(70)90027-5

Dal Bello, G. M.; Fusé, C. B.; Pedrini, N.; Padín, S. B. (2018) Insecticidal efficacy of Beauveria bassiana, diatomaceous earth and fenitrothion against Rhyzopertha dominica and Tribolium castaneum on stored wheat. International Journal of Pest Management, 64(3): 279-286. doi: 10.1080/09670874.2017.1397300

Kalsi, M.; Palli, S. R. (2017) Cap n collar transcription factor regulates multiple genes coding for proteins involved in insecticide detoxification in the red flour beetle, Tribolium castaneum. Insect Biochemistry and Molecular Biology, 90: 43-52. doi: 10.1016/j. ibmb.2017.09.009

Kamaruzzaman, A. H. M.; Reza, A. M. S.; Mondal, K. A. M. S. H.; Parween, S. (2006) Morphological abnormalities in Tribolium castaneum (Herbst) and Tribolium confusum Duval due to cyromazine and pirimiphos-methyl treatments alone or in combination. Invertebrate Survival Journal, 3(2): 97-102.

Khashaveh, A.; Ziaee, M.; Safaralizadeh, M. H.; Lorestani, F. A. (2009) Control of Tribolium castaneum (Herbst) (Coleoptera: Tenebrionidae) with Spinosad dust formulation in different oilseeds. Turkish Journal of Agriculture and Forestry, 33(3): 203209. doi: 10.3906/tar-0806-38

Kohlhepp, G. (2010) Análise da situação da produção de etanol e biodiesel no Brasil. Estudos Avançados, 24(68): 223-253. doi: 10.1590/S0103-40142010000100017

Lomakin, J.; Arakane, Y.; Kramer, K. J.; Beeman, R. W.; Kanost, M. R.; \& Gehrke, S. H. (2010) Mechanical properties of elytra from Tribolium castaneum wild-type and body color mutant strains. Journal of Insect Physiology, 56(12): 1901-1906. doi: 10.1016/j. jinsphys.2010.08.012

Lorini, I.; Krzyzanowski, F. C.; França-Neto, J. B.; Henning, A. A.; \& Henning, F. A. (2015) Manejo integrado de pragas de grãos e sementes armazenadas. Brasília: Embrapa.

Malekpour, R.; Rafter, M. A.; Daglish, G. J.; Walter, G. H. (2018) The movement abilities and resource location behaviour of Tribolium castaneum: phosphine resistance and its genetic influences. Journal of Pest Science, 91(2): 739-749. doi: 10.1007/s10340-017-0935-z

Nayak, M. K.; Falk, M. G.; Emery, R. N.; Collins, P. J.; Holloway, J. C. (2017) An analysis of trends, frequencies and factors influencing the development of resistance to phosphine in the red flour beetle Tribolium castaneum (Herbst) in Australia. Journal of Stored Products Research, 72, 35-48. doi: 10.1016/j.jspr.2017.03.004

Rees, D. P. (2008) Insects of stored products (Ynd ed.). Collingwood, Vic.: CSIRO Pub.

Richards, S.; Gibbs, R. A.; Weinstock, G. M.; Attaway, T.; Bell, S.; Buhay, C. J.; Sodergren, E. (2008) The genome of the model beetle and pest Tribolium castaneum. Nature, 452 (7190): 949-955. doi: 10.1038/nature06784

Silva, L. F. L. E.; Gonçalves, W. M.; Maluf, W. R.; Resende, L. V.; Sarmiento, C. M.; Licursi, V.; Moretto, P. (2017) Energy balance of biodiesel production from canola. Ciência Rural, 47(2): 1-5. doi: 10.1590/0103-8478cr20151084

Sitoe, M. D. (2013) Controle de Sitophilus oryzae L. em milho armazenado em grão. Londrina: UEL. http://www.bibliotecadigital. uel.br/document/?code=vtls000185945. Access on: 09.i.2020.

Trematerra, P.; Sciarreta, A.; Tamasi, E. (2000) Behavioural responses 
of Oryzaephilus surinamensis, Tribolium castaneum and Tribolium confusum to naturally and artificially damaged durum wheat kernels. Entomologia Experimentalis et Applicata, 94(2): 195-200. doi: 10.1046/j.1570-7458.2000.00619.x

United States Department of Agriculture-Foreing Agricultural Service - USDA-FAS. (2019) Oilseeds. https://www.fas.usda.gov/data/ oilseeds-world-markets-and-trade. Access on: 5.xii.2019.

Zaderimowski, R; Sosulski, F. (1978) Composition of total lipids in rapeseed. Journal of the American Oil Chemists' Society, 55(12): 870-872. doi: 10.1007/bf02671409

Zettler, L. J; Cuperus, G. W. (1990) Pesticide Resistance in Tribolium castaneum (Coleoptera: Tenebrionidae) and Rhyzopertha dominica (Coleoptera: Bostrichidae) in Wheat. Journal of Economic Entomology, 83(5): 1677-1681. doi: 10.1093/jee/83.5.1677

Yu, D.; Shrestha, B.; Baik, O. D. (2017) Thermal death kinetics of adult red flour beetle Tribolium castaneum (Herbst) in canola seeds during radio frequency heating. International Journal of Food Properties, 20(12): 3064-3075. doi: 10.1080/10942912.2016.1272609 